\title{
INTERNATIONAL TECHNOLOGY EXCHANGE IN'SUPPORT OF THE DEFENSE WASTE PROCESSING FACILITY WASTEFORM PRODUCTION
}

by

Bruce G. Kitchen

Westinghouse Savannah River Company

Savannah River Laboratory

Aiken, SC 29808

An abstract of a paper proposed for presentation at the International High-Level Rad Waste Management Conference

Las Vegas, NV

April 8-12, 1990

\section{DISCLAIMER}

This report was prepared as an account of work sponsored by an agency of the United States Government. Neither the United States Government nor any agency thereof, nor any of their employees, makes any warranty, express or implied, or assumes any legal liability or responsibility for the accuracy, completeness, or usefulness of any information, apparatus, product, or process disclosed, or represents that its use would not infringe privately owned rights. Reference herein to any specific commercial product, process, or service by trade name, trademark, manufacturer, or otherwise does not necessarily constitute or imply its endorsement, recommendation, or favoring by the United States Government or any agency thereof. The views and opinions of authors expressed herein do not necessarily state or reflect those of the United States Government or any agency thereof.

This paper was prepared in connection with work done under Contract No. DE-AC09-86SR18035 with the U.S. Department of Energy. By acceptance of this paper, the publisher and/or recipient acknowledges the U.S. Government's right to retain a nonexclusive, royalty-free license in and to any copyright covering this paper, along with the right to reproduce and to authorize others to reproduce all or part of the copyrighied paper. 


\title{
INTERNATIONAL TECHNOLOGY EXCHANGE IN SUPPORT OF THEDEFENSE WASTE PROCESSING FACILITY WASTEFORM PRODUCTION
}

\author{
Bruce G. Kitchen, Senior Consultant \\ Waste Technology Coordination, Savannah River Laboratory
}

The nearly completed Defense Waste Processing Facility (DWPF) is a Department of Energy (DOE) facility at the Savannah River Site that is designed to immobilize defense high level radioactive waste (HLW) by vitrification in borosilicate glass and containment in stainless steel canisters suitable for storage in the future DOE HLW repository. The DWPF is expected to start cold operation later this year (1990), and will be the first full scale vitrification facility operating in the United States, and the largest in the world.

Vitrification of high level waste is the process of choice of essentially all international HLW immobilization programs. The French and Germans have preceded the U.S. in radioactive operation at plant scale and several other countries have projects currently on a schedule paralleling and/or following ours. Still others are planning similar projects. Although the DOE's program is concerned with defense high-level wastes, the foreign programs deal principally with waste from reprocessing of commercial spent fuel. All of the nations involved in vitrification processes have had and are continuing in research and development programs that are designed to prove the viability of the process, demonstrate the ability to produce waste glass to predetermined specifications, and ensure the acceptability of the wasteforms in final respositories.

The DOE has been coordinating technology transfer and exchange on issues relating to HLW treatment and disposal through bi-lateral agreements with several nations. For the nearly fifteen years of the vitrification program at Savannah River Laboratory, over two hundred exchanges have been conducted with a dozen international agencies involving about five-hundred foreign national specialists. These international exchanges have been beneficial to the DOE's waste management efforts through confirmation of the choice of the waste form, enhanced understanding of melter operating phenomona, support for paths forward in political/regulatory arenas, confirmation of costs for waste form compliance programs, and establishing the need for enhancements of melter iacility designs.

This paper will compare designs and schedules of the international vitrification programs, and will discuss technical areas where the exchanges have provided data that have confirmed and aided U.S. research and development efforts, impacted the design of the DWPF and guided the planning for regulatory interaction and product acceptance. 


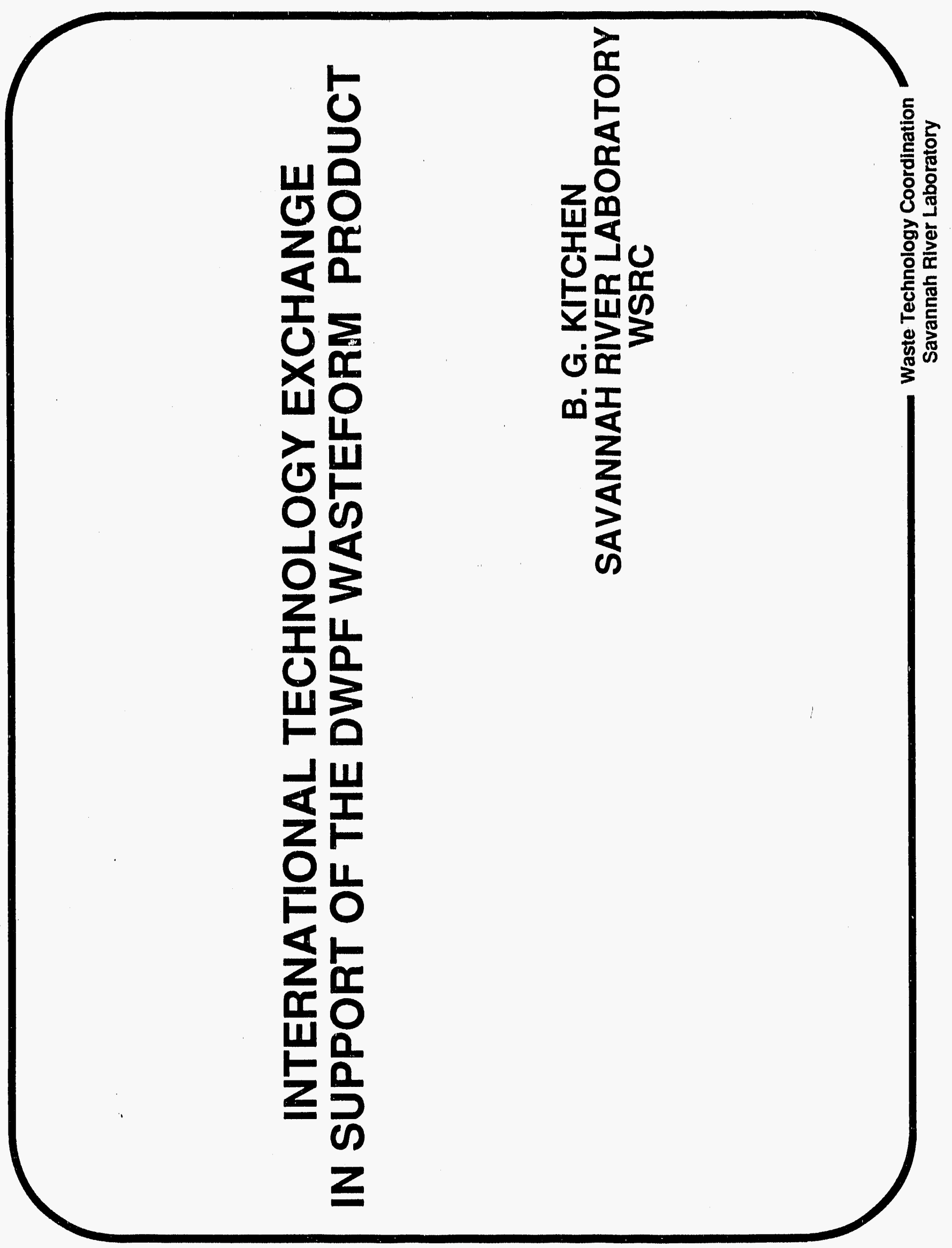




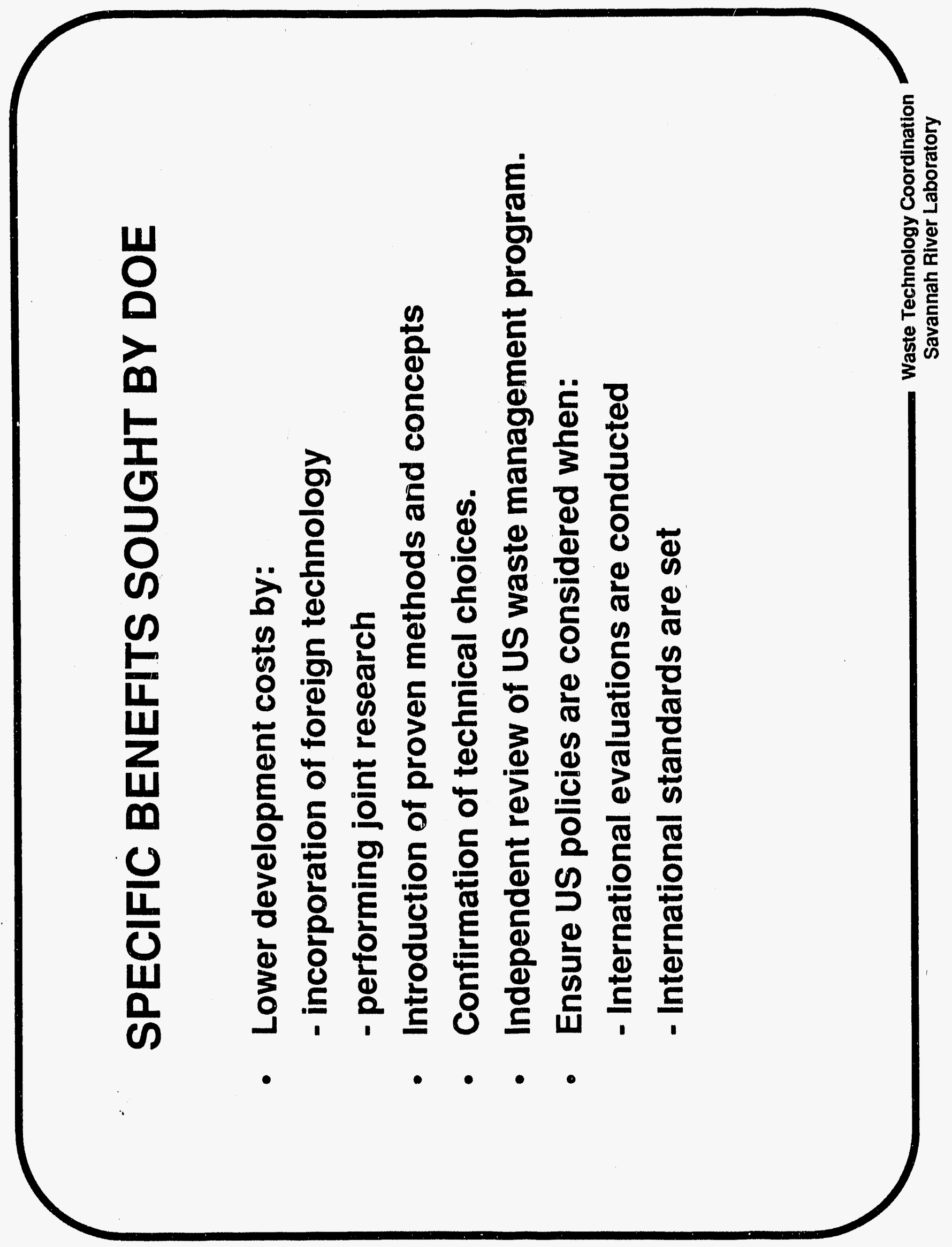




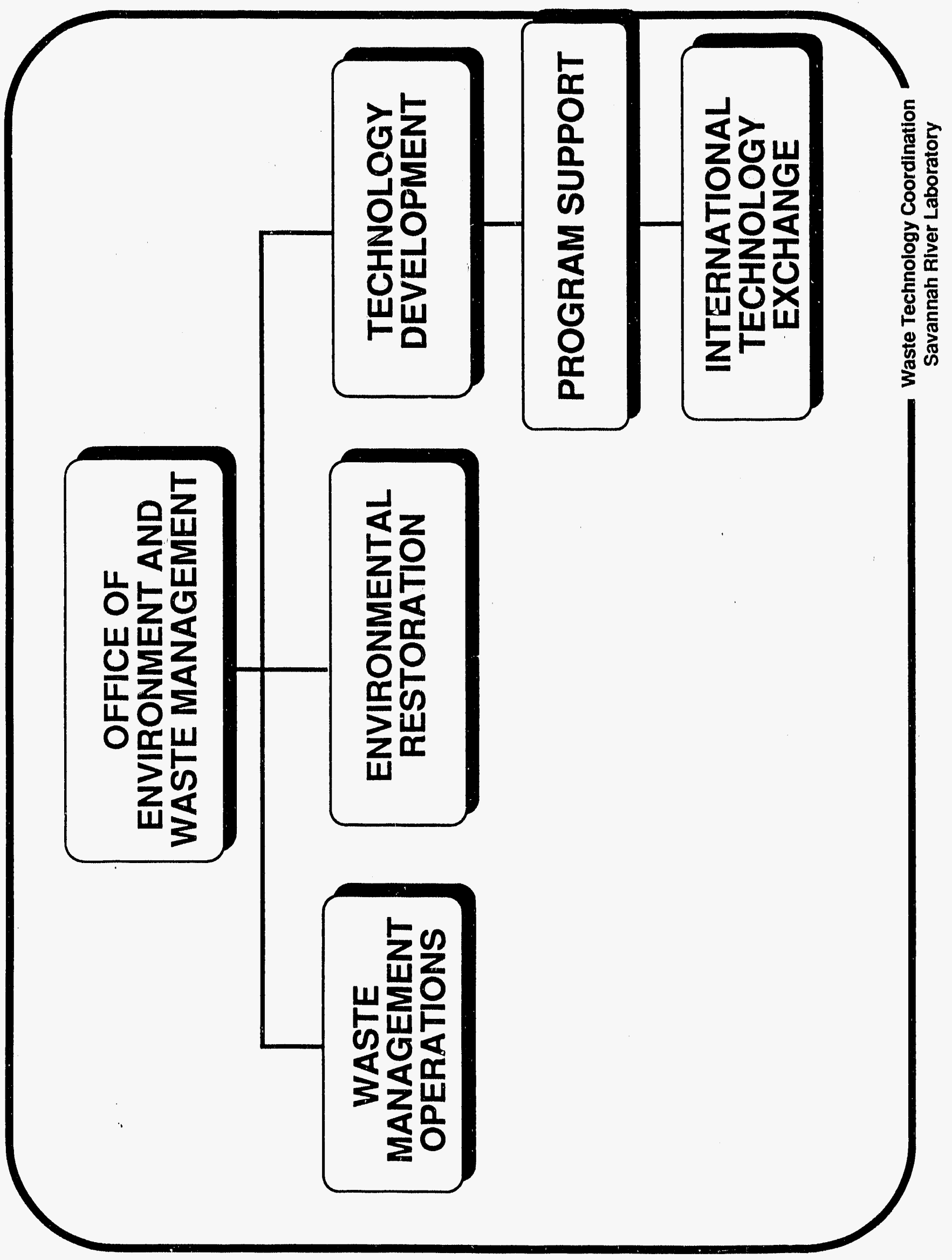




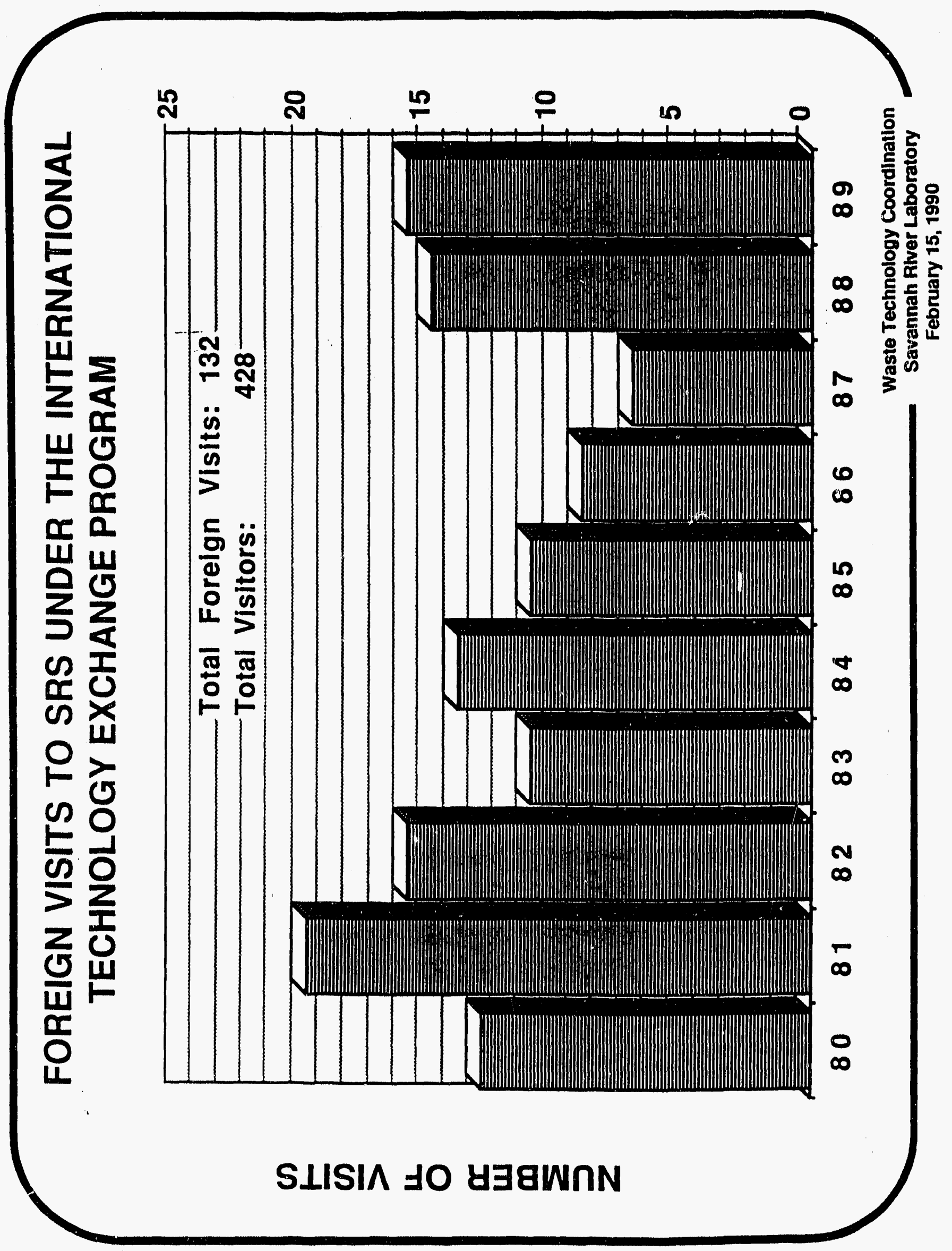




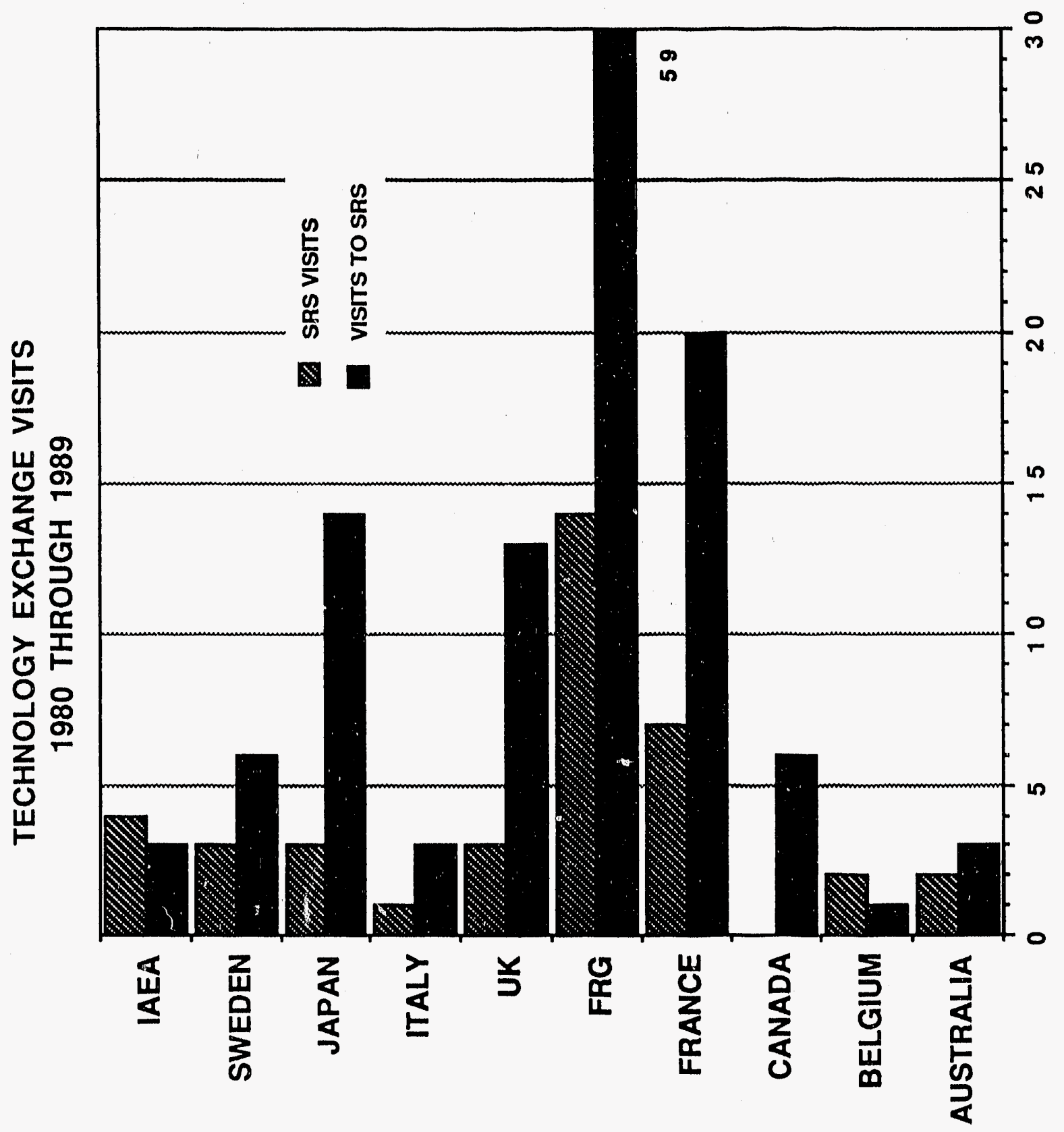




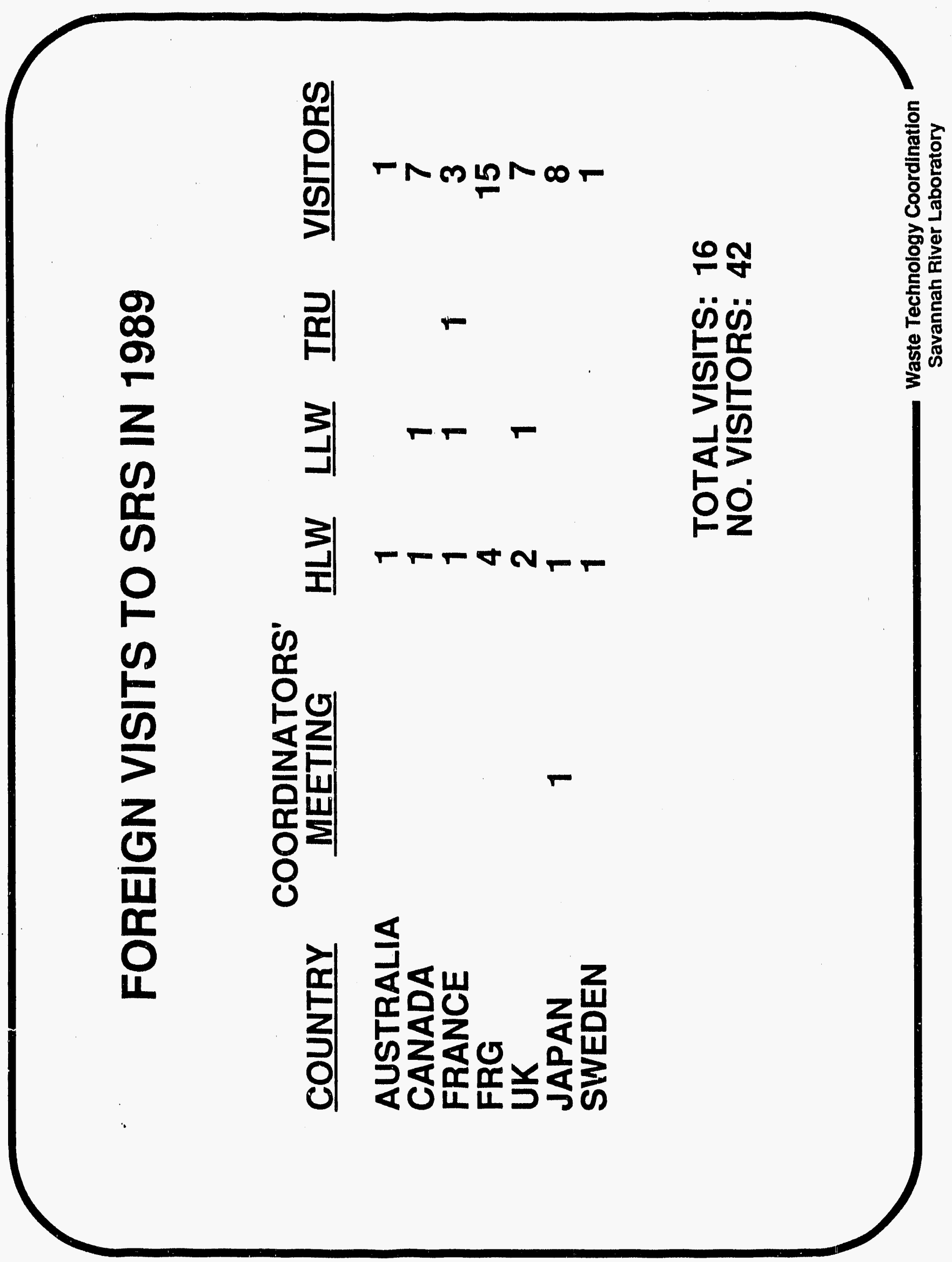




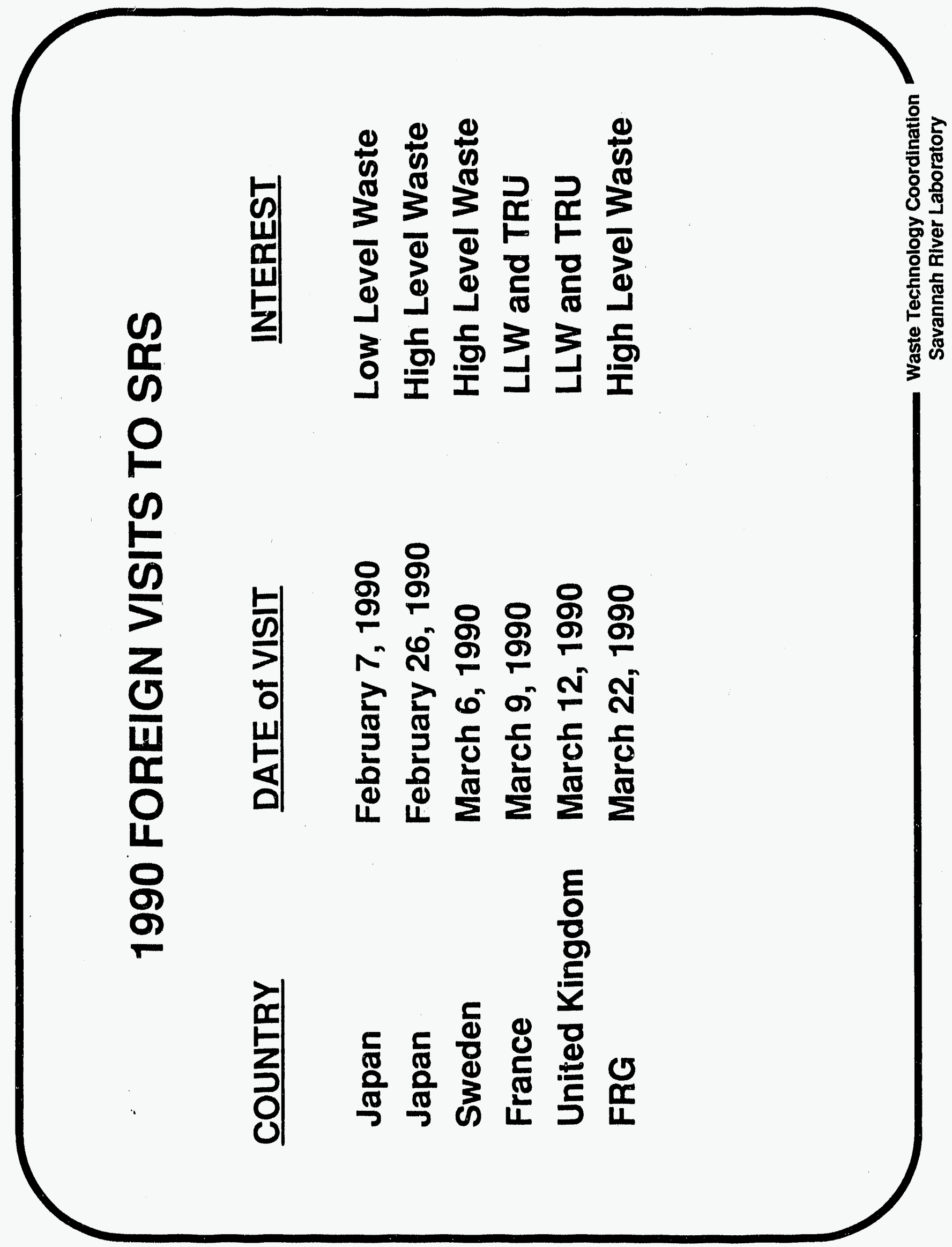




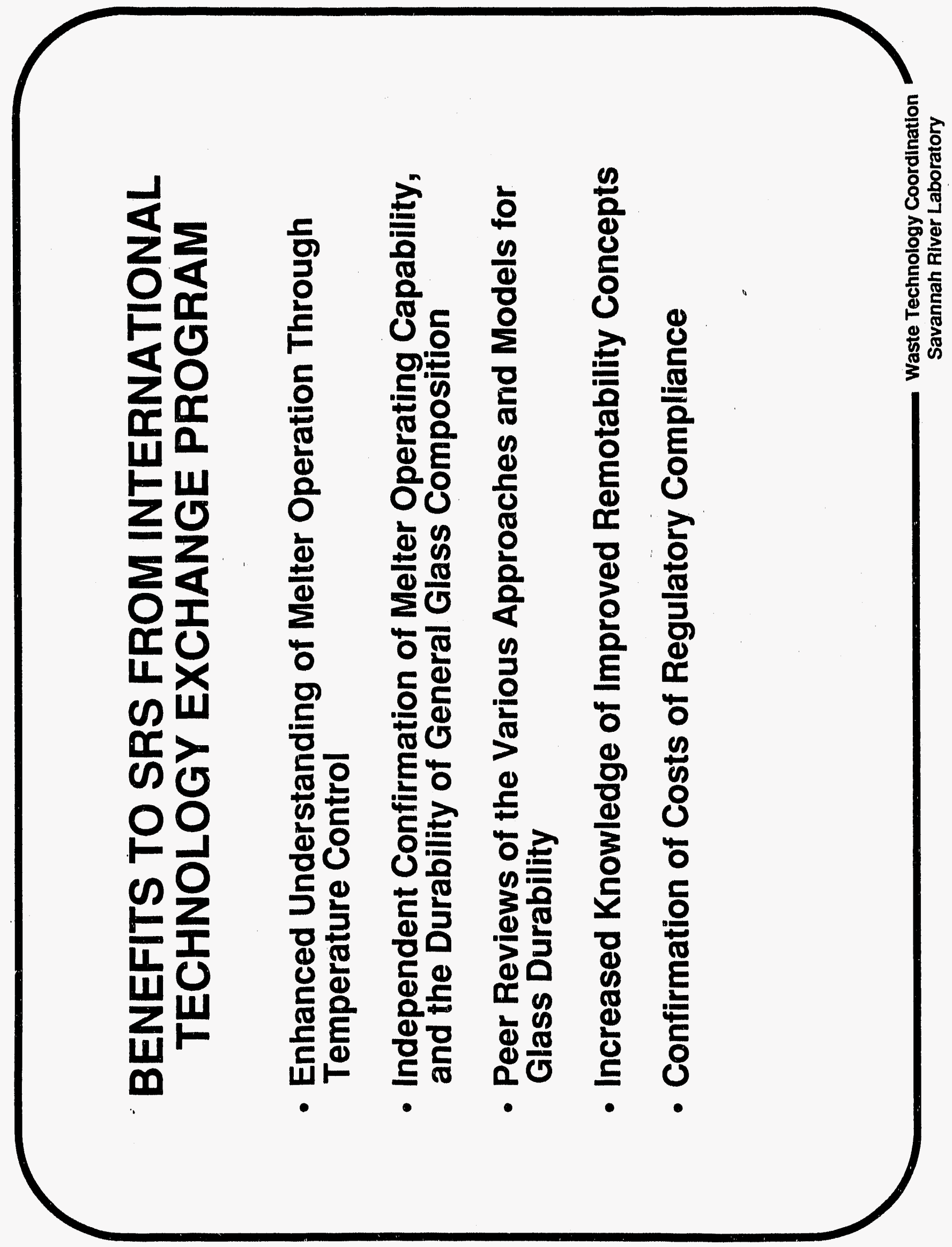




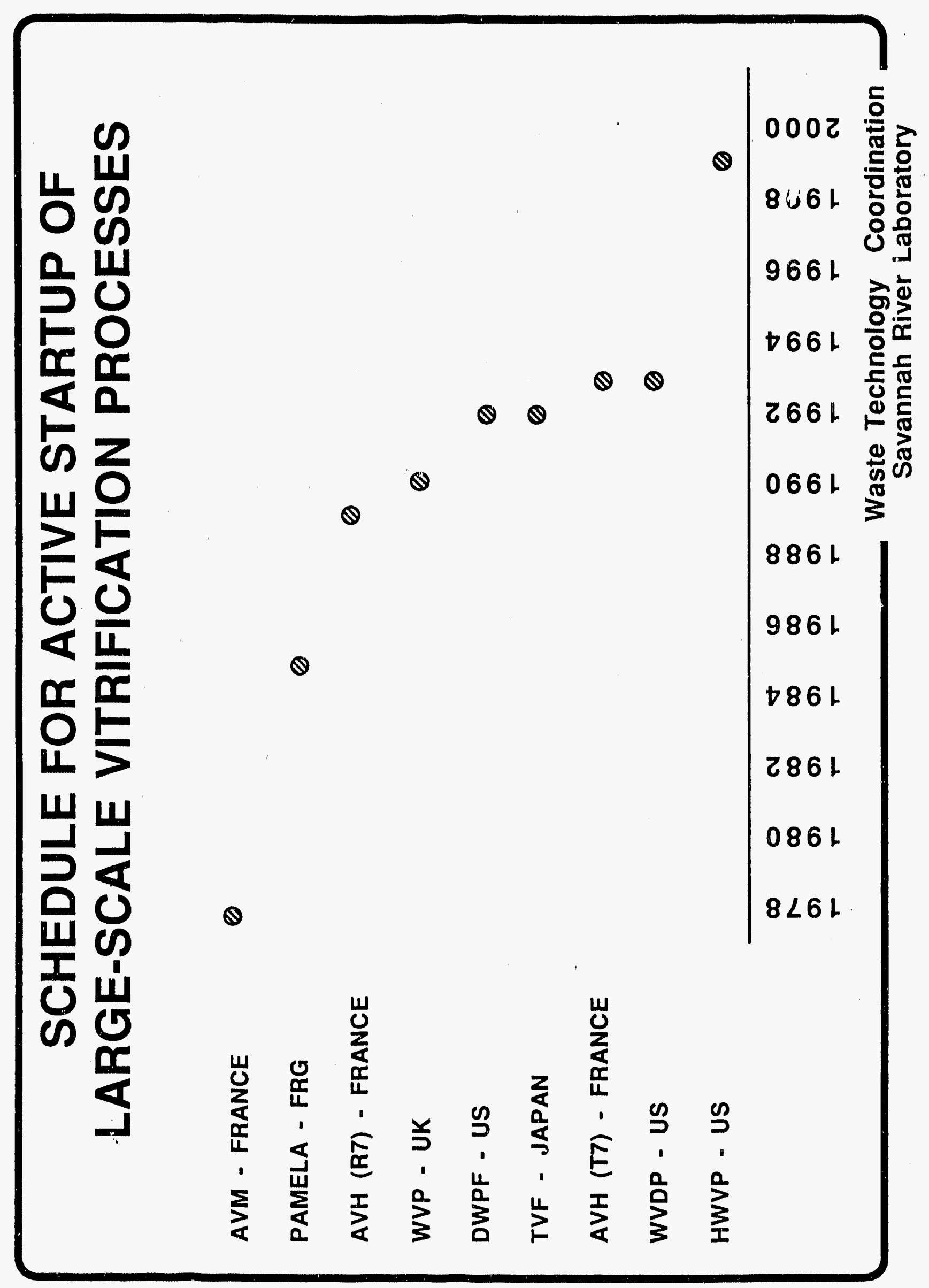




\section{United States - DWPF}

The Savannah River Site has been operating a nuclear fuel cycle since the early 1950's. Fuel and target elements are fabricated and irradiated to produce nuclear materials. After removal from the reactors, the fuel elements are processed to extract the products, and the waste is stored in underground tanks. During the 35 plus years of operation, about 83 million gallons of waste have been generated. This waste has been reduced to about 33 million gallons by evaporation in the waste tank farms. The Department of Energy has built and will operate a facility to vitrify this high-level radioactive waste. The Defense Waste Processing Facility (DWPF) will solidify existing and future radioactive wastes by immobilizing the wastes in durable borosilicate glass contained in stainless steel canisters. The canisters will be sealed, decontaminated and stored prior to emplacement in a federal repository.

The SRS high-level radioactive waste is currently stored on site in carbon steel tanks as either an insoluble sludge or a salt fraction made up of saltcake and salt solution. The salt portion is decontaminated in the storage tanks for disposal as low-level waste by precipitating the radionuclides. The decontaminated salt solution is blended with cementacious slag, flyash and cement in a separate facility as low-level waste. Sludge waste is also pretreated in existing waste storage tanks to dissolve soluble, nonradioactive ingredients such as aluminum, so that they may be processed with the salt solution into low-level waste rather than the more costly high-level waste glass. Within the vitrification building the salt precipitate is processed to remove organics in a formic acid hydrolysis process. The washed sludge and the precipitate hydrolysis product are mixed with borosilicate glass frit to become feed to the melter system.

Vitrification of the HLW waste stream is accomplished in a slurry-fed Joule-heated melter. Glass is normally removed from the bottom of the DWPF melter through a riser which is slanted upward, and overflows into a pour spout connected to the stainless steel canister. When the canister is rotated away from the melter pour spout, a tapered plug is inserted into a sleeve in the canister opening. Cooling of the sleeve in the canister neck creates a shrink-fit, water-tight seal.

Frit slurry blasting is used to remove contamination and metal oxides from the canister surface. The canister is permanently sealed by welding a plug into the canister nozzle using an upset resistance weld. The filled and decontaminated canisters are moved by a shielded transporter and stored in an air-cooled interim storage building. The canistered waste forms will be shipped from the interim storage building to a federal repository, when it is available.

Essentially all of the process steps and major equipment pieces of the DWPF have been demonstrated in R\&D studies at the Savannah River Laboratory.

The saltstone grout process has been demonstrated cold full-scale. The decontamination of the salt solution has been demonstrated full-scale in the waste tanks, and the hydrolysis of the precipitate has been demonstrated on 1/5-scale. Further process development on the hydrolysis process is underway. Several specific key melter design concepts were demonstrated using a $2 / 3$-scale non-radioactive melter, two years operation of this melter have provided confidence in the DWPF design. The off-gas system has also been demonstrated on the $2 / 3$-scale melter. A prototype of the melter drain valve has been tested at SRL. The cleaning and closure of the stainless steel canisters have been demonstrated full-scale using actual DWPF equipment.

The full chemical flowsheet, including mercury, halides and noble metals, is now under test in a 1/9-scale Integrated DWPF Melter System. The process development work is aimed principally at defining optimum operating points and acceptable operating windows for the various process parameters.

The selection of borosilicate glass for immobilizing HLW in the DWPF resulted from over 
30 years of R\&D studies in many laboratories throughout the world. The glass demonstrates radiation stability, chemical durability, mechanical integrity, thermal stability, processability and structural flexibility to accept many different waste elements at varying compositions. Currently a very extensive effort is being devoted at SRS to assure that the DWPF product will be of the same high quality that has been produced in laboratory tests on a pilot scale basis, and will therefore be acceptable for disposal in a federal repository.

At the end of 1989 , the physical completion of the DWPF facility was $97 \%$. The last canyon processing area was turned over from construction to operating forces in November 1989. The commissioning or component testing phase of startup stands at $70 \%$ complete.

The distributed control system hardware checkout is $96 \%$ complete. Cold testing of the DWPF is now scheduled to start with integrated water runs in September of this year.

The start of radioactive operations is still scheduled for 1992. 


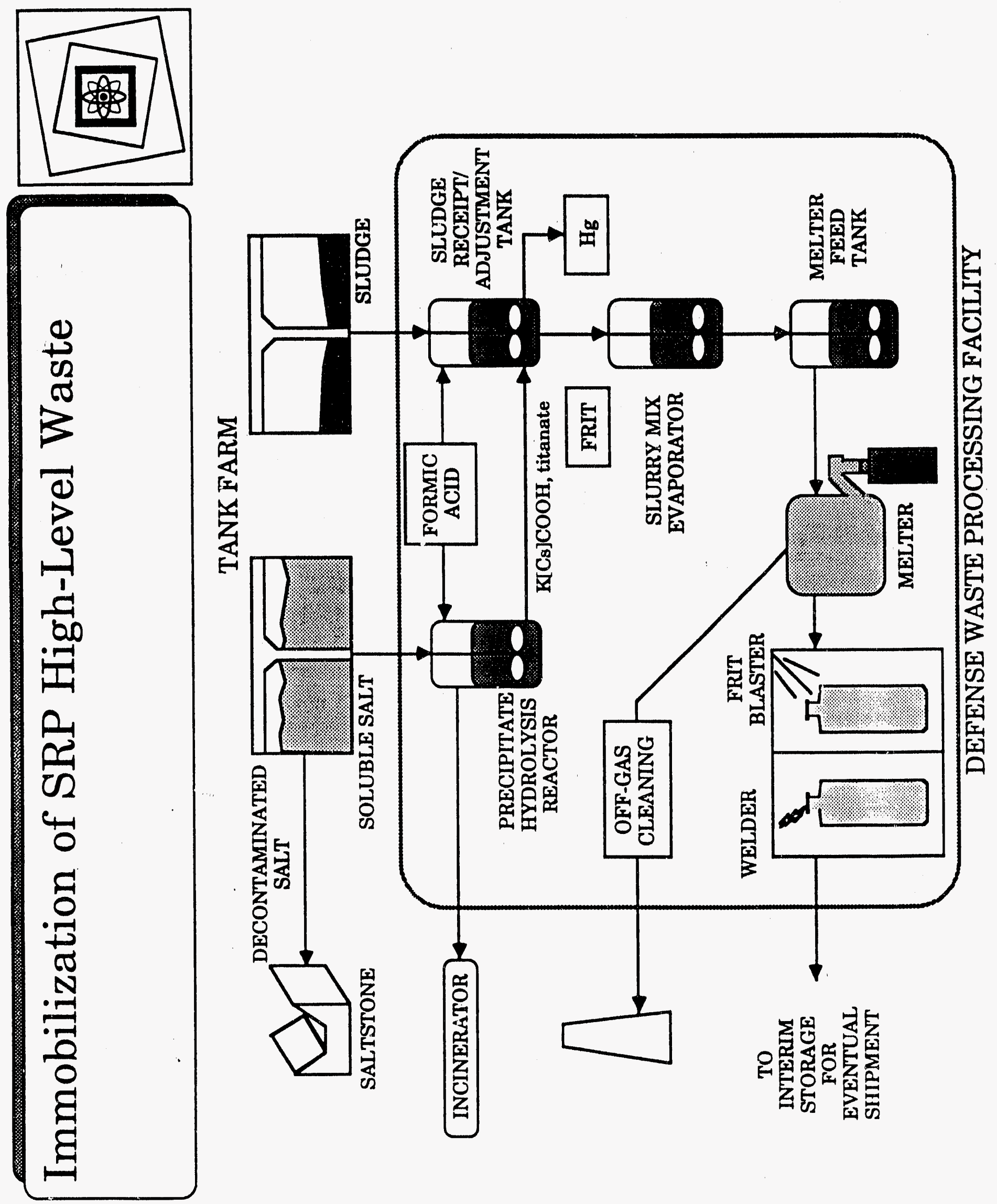




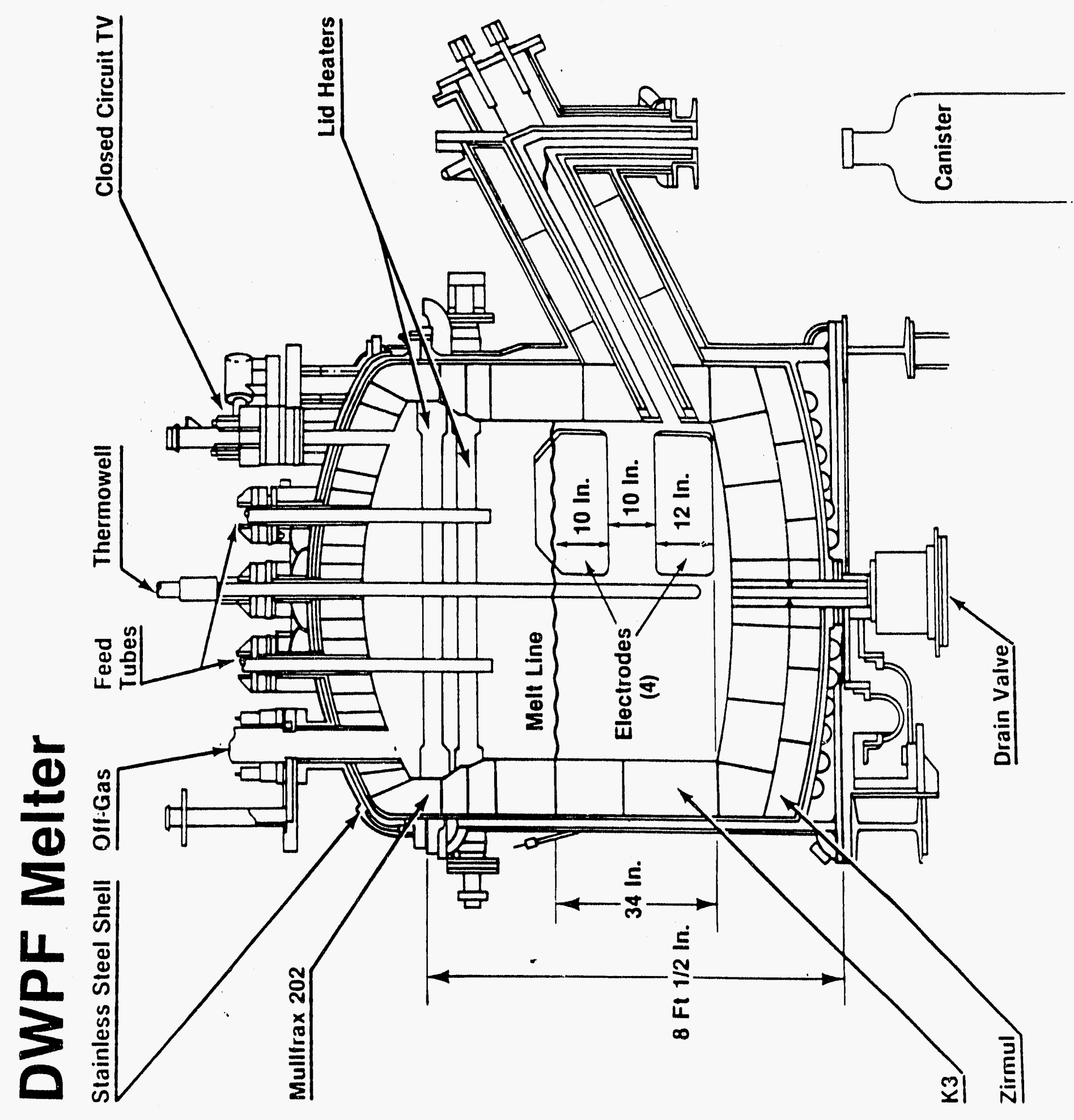


After filling by two $200 \mathrm{Kg}$ pours (one pour every 8 hours) each canister is transferred to another cell for:

- cooling by natural convection in a metal shroud to limit glass fracturing

- plasma arc welding of the lid

- non-contamination inspection of the entire external surface by a wipe-test robot.

Non-contaminated canisters (i.e. surface contamination less than $3.7 \mathrm{E5} \mathrm{Bq} / \mathrm{m}$ ) are then transferred under biological shielding to a pit in the interim storage facility. Contaminated canisters are washed by high pressurized water in a decontamination tank and then again inspected by an identical robot but in a different cell.

Solld engineering wastes produced during component replacement and maintenance operations are transferred to a dismantling cell for:

- size reduction by sawing and shearing,

- decontamination in a reagent tank when necessary

- according to the level of activity, either transfer out of the vitrification unit in a special overpack or packaging in containers identical to the glass canisters and after decontamination and verification of outer surface non-contamination transfer to the interim storage facility.

The central control system comprises 50 programmable controllers which allow:

- a real-time control system enabling operation in automatic, semi-automatic or normal modes,

- a safety control system which ensures that the facility can always be placed in a safe configuration and that equipment whose failure may have a significant impact on safety can be suitably controlled. This system is fully independent of the previous one. The safety panel is located in the control room at the shift supervisor's station. - an auxiliary control system which enables monitoring of process variations and equipment operations. The auxiliary control panel is located in a room accessible from outside the plant, even after an earthquake.

The overall dimensions of the facility are $101 \mathrm{~m} \times 61.5 \mathrm{~m} \times 43 \mathrm{~m}$. R7 has carried out nonradioactive runs in 1988. The radioactive startup came up in June 1989.

$\uparrow 7$

T7 is also located at La Hague. Ht will serve the future UP3 reprocessing plant (capacity 800 $\mathrm{t} / \mathrm{y})$. T7 is a facility absolutely identical to R7 to the various aspects of the vitrification process (number of lines, dismantling principle etc..). The layout is almost the same as R7 one.

Consequently, as six identical vitrification lines are operated at La Hague, all mechanical and fabricated components are totally interchangeable, which minimizes spare inventory.

T7 is scheduled to begin hot operation in 1990 . 


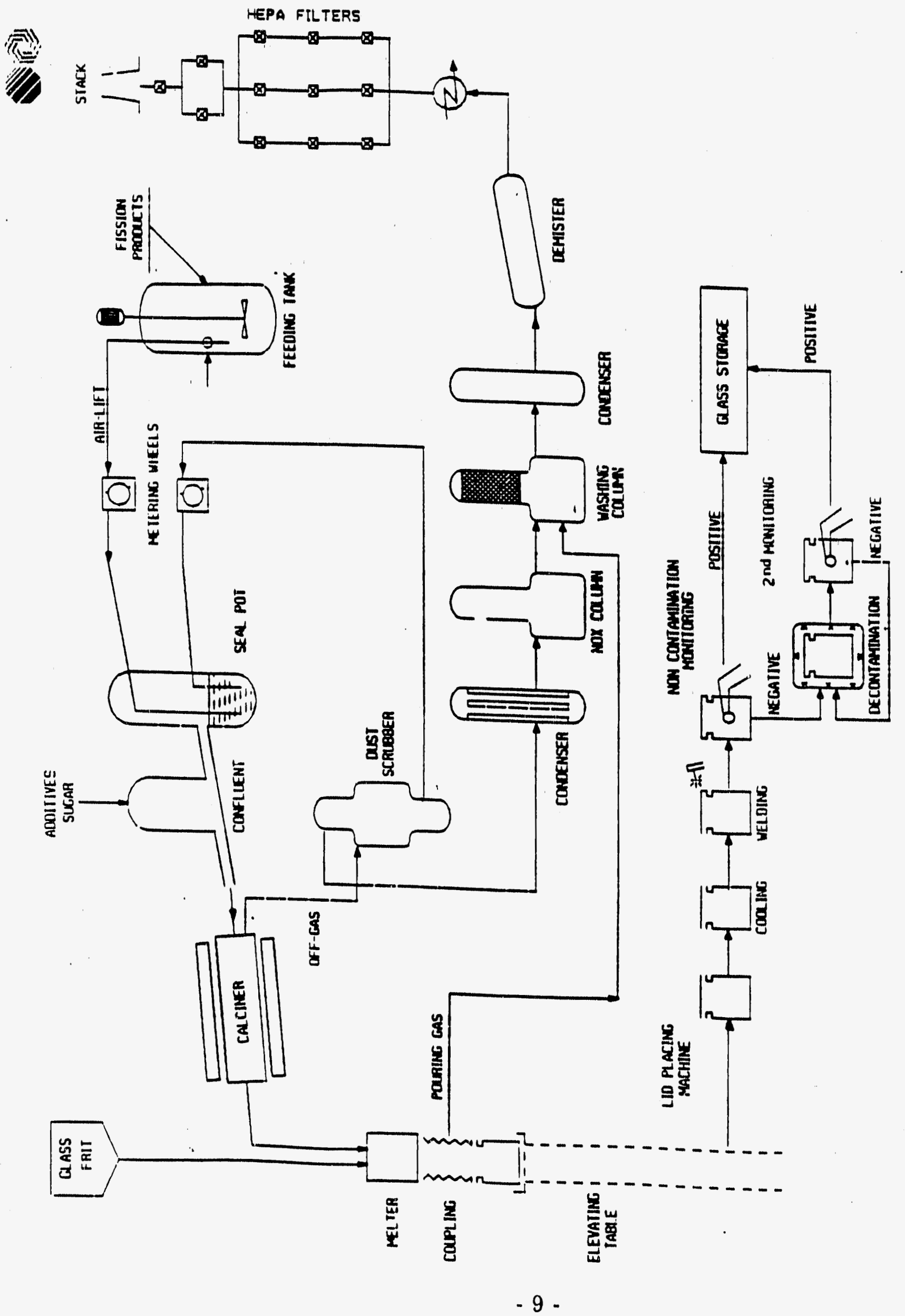

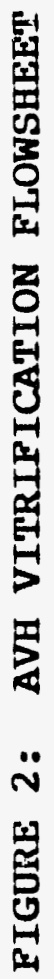



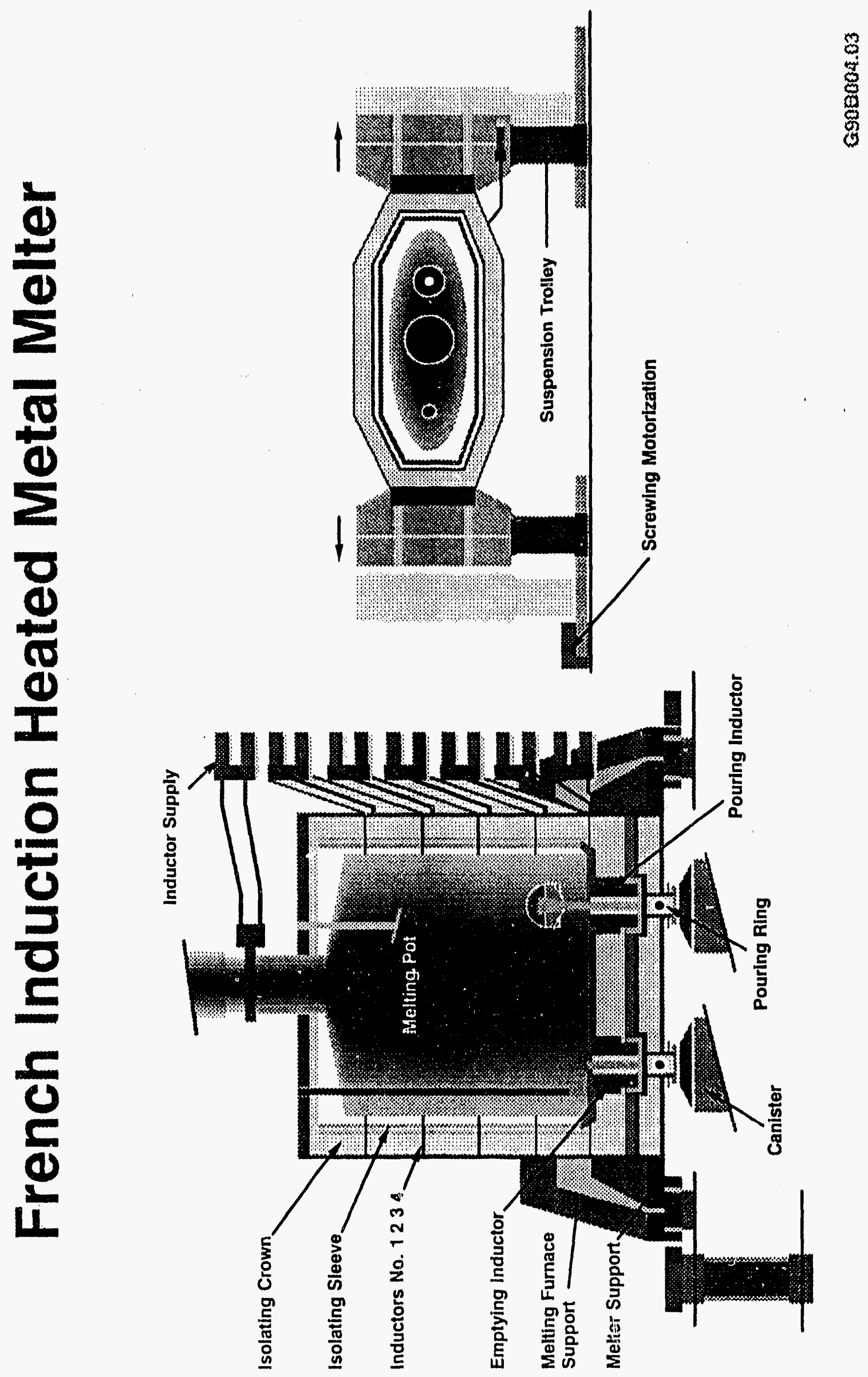
Since the mid-70's the activities in high-level waste treatment in the Federal Republic of Germany had been primarily directed to the development and testing of the vitrification technique known as the liquid-fed ceramic melter (LFCM) process. In 1978 the PAMELA project was established to construct an active pilot demonstration plant at the Eurochemic site at Mol, Belgium to demonstarate the feasibility of the LCFM process and to immobilize Eurochemic's existing low-enriched waste concentrate (LEWC) in borosilicate glass. The PAMELA plant was constructed on schedule from 1981 to 1984. Radioactive operation commenced on schedule on October 1, 1985. The existing 50 cubic meters of LEWC were successfully vitrified by May of 1986.

As the overall performance of the plant was considered fully satisfactory, it was decided to use the PAMELA plant for routine operation in solidifying the high-enriched waste concentrate (HEWC) resulting from the reprocessing of highly enriched MTR fuel. According to the agreement between the German and Belgium governments, the PAMELA plant changed to Belgian hands after the LEWC campaign. Under the responsibility of Belgoprocess, the successor to Eurochemic, startup of HEWC vitrification occurred October 1, 1986. By May 1989 about 400 cubic meters of HEWC solution have been immobilized.

The LCFM technology applied in PAMELA was principally developed at the Institut fur Nukleare Entsorgungstechnik (INE) of the Karlsruhe Nuclear Research Center (KfK). Between 1976 and 1983, three generations of electric glass melters were designed and operated in inactive test facilities, producing more than 100 tons of simulated glass product. The third generation melter, designated K-3, was the candidate reference melter for active operation. Apart from slight modifications, it was identical with the PAMELA radioactive melter. The K-3 melter was used in the cold process demonstration and was operated in 1983 in a full-scale mockup facility under remote conditions. Later, this melter was used for inactive testing at the PAMELA plant in Mol.

The K-3 design feed rate (LEWC) is $30 \mathrm{~L} / \mathrm{h}$ and glass production rate is $30 \mathrm{Kg} / \mathrm{h}$. The glass pool is characterized by an average volume of about $330 \mathrm{~L}$ and a square pool surfact of $0.72 \mathrm{~m}$. The volume difference between maximum and minimum level, designated as discharge volume and equivalent to a canister filling is $60 \mathrm{~L}$. The melter is completely encased in a stainless steel box with outside dimensions of $2.6 \mathrm{~m} \times 2 \mathrm{~m} \times 2 \mathrm{~m}$.

It weighs 18 tons.

The melter is equipped with four independent sets of Inconel 690 plate electrodes; two lower sets along the melter floor and two upper sets a few $\mathrm{cm}$ below the minimum glass level in the tank. They are located in the opposite walls of the melter. The arrangement provides the possibility to vary and distribute the power where it is actually needed. The normal power distribution is $60-70 \%$ for the lower electrodes. The maximum power input available for the melter is in the range of $100 \mathrm{Kw}$.

Each electrode is provided with an air-cooling system on its back side to keep the immersed electrode below $1100 \mathrm{C}$. maintaining the electrode temperature below this level is necessary to ensure the life of the Inconel 690 material. Another factor shortening electrode life is the curent density. According to the results of experiments in the first two melters, current densities must be kept below 0.8 amperes/cm squared. For that reason, the power supply for each set of electrodes is current-controlled. A current-controlled melter aslo provides self-regulation, in that the power released to the glass pool decreases if the temperature of the glass increases. Increasing temperature is associated with higner 
electrical conductivity and, thus, power. The temperature during operation is maintained at $1150 \mathrm{C}$.

For start and restart the melter is equipped with $20 \mathrm{MoSi} 2$ electrical resistance heating elements. These are placed behind the refractory of the melter plenum. After termination of the heating-up procedure, when the glass has become electrically conductive, they are removed from the melter.

For the discharge of glass product two systems are at disposal: a bottom drain freeze valve system and an overflow. The routine discharge for the production of glass blocks is performed by the bottom drain. It conisists of a ceramic channel in the upper part and a metallic tube made in Inconel 690 forming the lower part. Two different heating circuits are used to raise the glass temperature in the outlet channel for start of the glass flow. The ceramic part of the channel is heated by electrode direct heating, whereas the metallic pin is heated by a mean-frequency heating system. Termination of the glass flow is achieved within a few minutes after switching off both circuits. All parts of the bottom drain equipment except the metallic pin can be remotely exchanged.

The overflow system consists of a vertical and a horizontal glass channel. The horizontal part is heated by three resistance heaters and by direct heating with two pairs of lateral electrodes, a so-called RHF heating system. A nitrogen-driven glass airlift, inserted in the vertical (riser) channel helps to increase the glass flow rate. During the radioactive process demonstration of PAMELA, the overflow drain in combination with a bead production unit served for the production of glass beads. These were filled into canisters and subsequently the pore spaces of the fill were casted with molten lead (VITROMET product). Apart from that special production, the overflow is being considered as a redundant discharge system in case of failure of the bottom drain.

Process control of the melter is achieved by temperature monitoring with three thermocouples placed in different heights of the melter plenum. The lowest one served for control of the melt level, whereas the two upper ones deliver information about the process conditions on the glass pool surface, especially about the extent of the "cold cap" coverage.

The melter is fed by two separate lines through an air-cooled feeding tube which is centrally located on the top of the melter. The waste solution is continuously introduced by airlift from a small feeding vessel, which on its part is periodically filled from the receiving tank by means of a double-stage vacuum-supported airlift system. The glass forming material consisting of a premelted frit in form of beads is directly fed to the melter in batches. Gases exit the melter through a lateral, remotely exchangeable off-gas pipe equipped with a motor-driven brush to clean the tube from deposits when needed. The exhaust has to undergo a precleaning in a dust removal wet scrubber before leaving the melter cell. Further wet scrubbing is performed in the first off-gas cell, containing a condenser, a jet scrubber and a NO -absorber. The secondary wastes arising here are collected, concentrated by evaporation and recycled to the receiving tank. After passing the scrubbing area, final gas cleaning takes place in the second off-gas cell, equipped with a glass fibre type high efficiency mist eliminator (HEME) and two HEPA-filters in series.

The waste glass is drained into stainless steel canisters. The level is continuously controlled by weight and additionally a gamma detection system controls the maximum level. Draining the discharge volume of $60 \mathrm{~L}$ requires about $70-90$ minutes. The filled canisters aïe subsequently cooled, decontaminated and after a smear test are brought to an intermediate storage. 
The radioactive demonstration of the PAMELA process was completed eight months after radioactive start-up. During that time, the existing $50 \mathrm{cu}$ m of LEWC were converted into 78 tons of glass in 542 canisters (442 glass blocks and 100 VITROMET canisters. In total $2.8 \mathrm{x}$ $10 \mathrm{E} 17 \mathrm{~Bq}$ of beta-activity have been immobilized in glass.

The experience from this worldwide first processing of original high-level waste by LFCM technique was very promising. The time avallability of the plant was around $90 \%$, the efficiency of throughput was around $85 \%$. More than $99.8 \%$ of the activity introduced into the system could be fixed in the glass. Feed-to-stack decontamination factors of more than 10 to 13 th were obtained. The total alpha-emission to the stack was only $0.01 \%$ of the licensed value (2.7 E7 Bq/a) and the beta-emission $0.03 \%$ (5.2 E9 Bq/a). The maximum individual radiation dose to an operator was $4 \mathrm{mSv}$, the average dose was $1.7 \mathrm{mSv} /$ year.

During the vitrification of the LEWC, a quantity of approximately $90 \mathrm{Kg}$ of noble metals (Pd, $\mathrm{Rh}, \mathrm{Ru}$ ) was fed into the melter of which $64 \mathrm{Kg}$ were Ruthenium. A quantity of $30-60 \mathrm{Kg}$ of noble metals was accumulated in the melter, forming a layer of a few $\mathrm{cm}$ thick on the flat bottom. Noble metal-enriched glass samples taken from the melter showed an electrical resistance three times lower and a viscosity about five times higher than those of the normalk LEWC glass at $1150 \mathrm{C}$. The observed decrease of energy consumption in the melt could thus be expleined because a significant portion of the current passed through the highly conductive bottom glass layer.

Besides the LEWC campaigns, experience is available from the vitrification of $400 \mathrm{~m}$ of HEWC, which is characterized by a high content of aluminium and a considerable mercury concentration. Due to the low content of noble metals in that waste solution, it did not contribute to the accumulation of noble metals on the melter floor. There was even some evidence to assume that some of the noble metals retained in the melter from the previous LEWC campaigns might have flushed out during the HEWC processing.

In Summer 1988, it was decided to replace the first active melter by a new one (K-5). The first active melter K-4 was in continuous operation for about three years in total processing $275 \mathrm{cu} \mathrm{m} \mathrm{HLLW}$ to 218 tons of waste glass. Reasons for the exchange were problems with bottom drain and a leak in the riser block, making the glass airlift operation inefficient. Remote removal of the old and installation of the new melter were accomplished within two months. Up to May 1989 the second melter, under operation, since August 1988, has processed another $177 \mathrm{~m}$ of HLLW.

Since 1984, the main activities in the field of HLLW management in the Federal Republic of Germany have been directed to the further development of the PAMELA process with respect to large-scale application in a commercial reprocessing plant. Such a plant was under construction at Wackersdorf (WAW) since 1985. In 1989, tho Government decided to stop its completion.

As indicated above, commercial wastes are characterized by a high content of noble metals, which in case of accumulation in the melter can handicap the vitrification process. To avoid that problem, the design for the WAW melter has been changed to a new configuration for the melter bottom. A full-scale melter with a HLLW design feed rate of 72 L/h and equipped with a sloped bottom of 45 degrees has been operated since early 1988 in a remotely equipped mock-up facility at INE/KfK. 
General conclusions of the technical experiments (which are supported by results of physical and mathematical modelling) are that a sloped bottom is a sultable means to force the discharge of the high-viscous noble metal-enriched glass layer formed on the melter bottom. However, the degree of the slope should probably be higher than 45 degrees to increase the downstream velocity along the inclined walls thus reducing the thickness of the noble metal-enriched high-conductive glass layer to a minimum. With regard to the vitrification of the HLLW of the WAK plant, which in terms of Platinurn metals is typical for a commercial waste, another melter has been developed at INE/KfK. It has sloped bottom walls with an inclination varying between 60 and 75 degrees. The melter is currently under construction and will be put into operation in the beginning of 1990. 


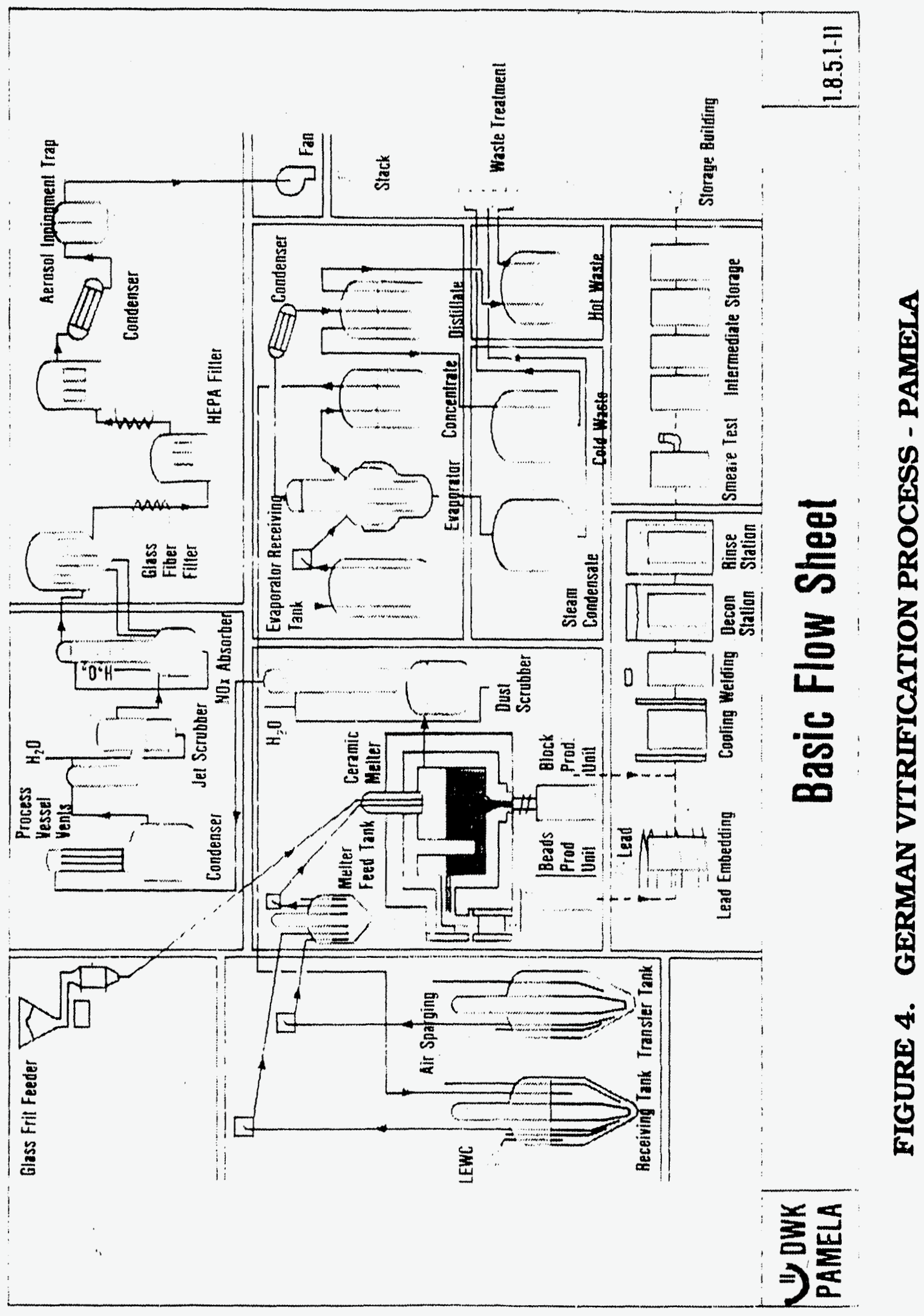




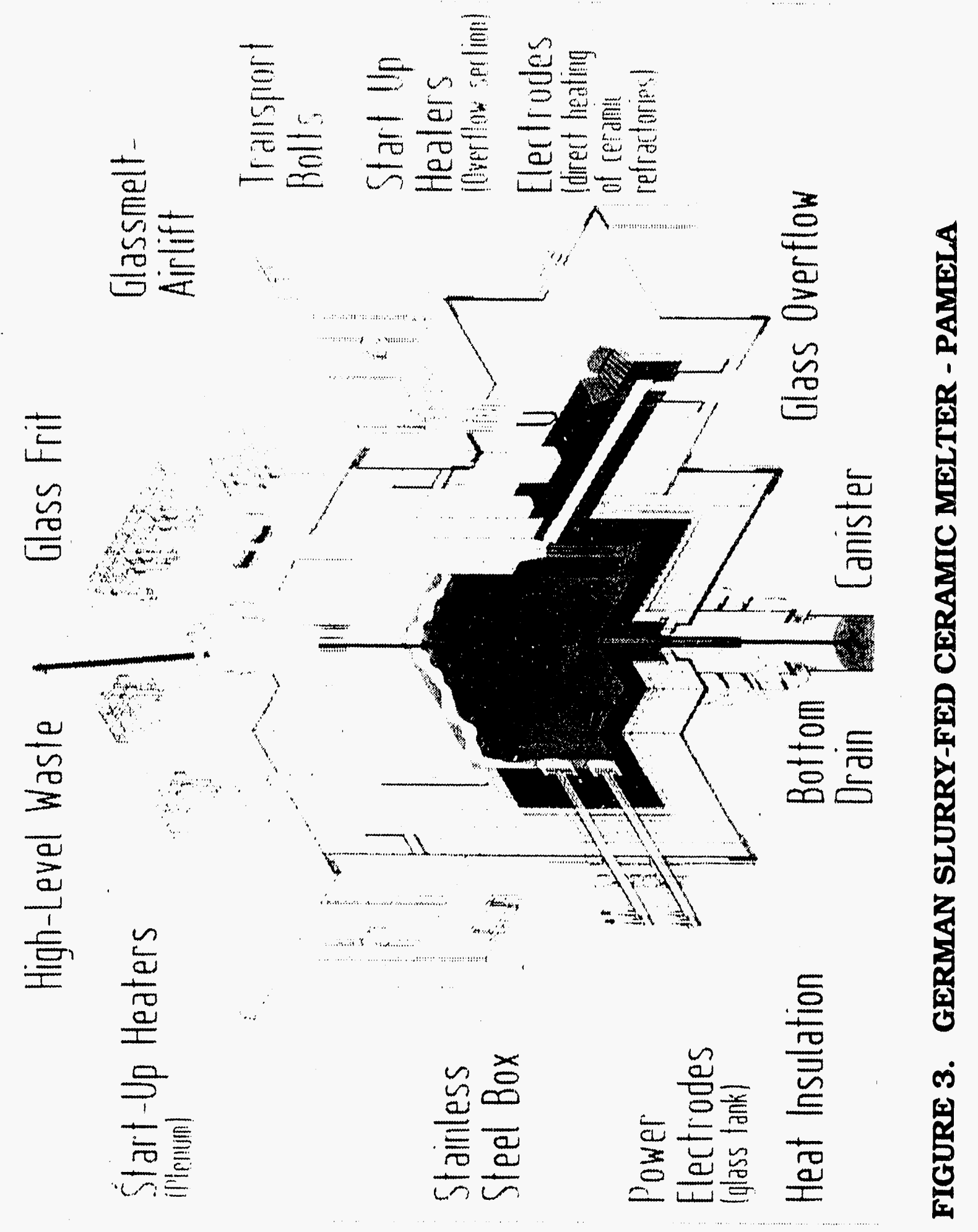


WVP has been erected at Sellafield (formerly Windscale) for the purpose of vitrifying the high-level liquid wastes generated by the reprocessing of Magnox fuel as well as those that arise from the Thorp reprocessing plant devoted to LWR and AGR spent fuels, and that is planned to be in operation in 1992. It is intended that the same borosilicate base glass will be used for both waste streams 6].

The main vitrification equipment in WVP is the same as that installed in the French process for R7 or T7. However, the different layout in WVP provides two fully independent processing lines up until the canister decontamination stage. The use of two lines allowed a relatively compact facility ( $64 \mathrm{~m}$ long, $38 \mathrm{~m}$ wide, $40 \mathrm{~m}$ high) to be built. Each vitrification cell contains feeder, calciner, melter and dust scrubber. Each vitrification cell is connected directly to a breakdown cell, a pouring cell and a decontamination cell. Equipment for the remote maintenance, dismantling, cutting and packaging of waste is provided in each cell. The pouring cell contains lid placing, cooling stations and lid welding equipment. A decontamination cell common to both vitrification lines contains a high pressure waste decontamination tank. A common control cell contains a machine to externally wipe the container and a wiper transfer monitoring system. In addition, a number of cells containing the low-level effluent system, nitric recombination columns, hoist park, secondary off-gas treatment, and filters are provided.

Since 1983, a Full Scale Inactive Facility (FSIF) has also been in operation at Sellafield. Based on the AVM design, it has so far produced (by 1989) over 50 metric tons of inactive glass. Possession of the facility and other ancilliary equipment has allowed BNFL, to: - obtain a through understanding of the process -optimize the flowsheet for Sellafield wastes and a UK developed borosilicate glass formulation. -demonstrate operation of the process and characteristics of the product to the UK regulatory authorities. -substantially reduce the anticipated commissioning time of the main plant.

The FSIF programme of work is scheduled for completion in late 1989 to coincide with the start of chemical commissioning of WVP, which is scheduled to start radioactive operation in 1990. 


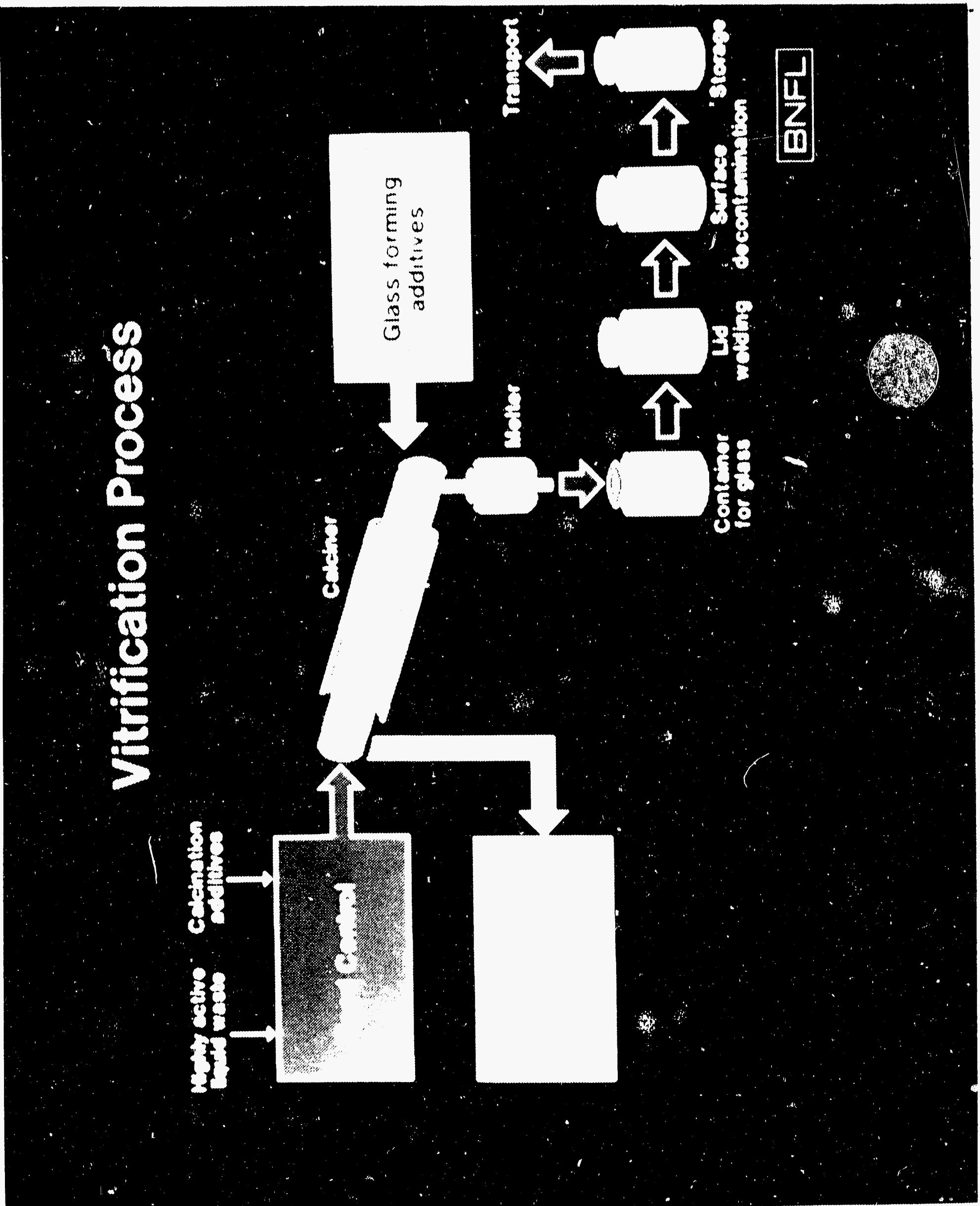


The Tokai Reprocessing Plant is the first reprocessing facility in Japan. Approximately 400 cu $\mathrm{m}$ of high-level liquid waste has been generated from reprocessing LWR fuel and stored in on-site tanks. The Japanese policy for the treatment and disposal of HLLW is that it shall be vitrified into a stable form, cooled for 30 to 50 years and then disposed into a deep geological formation.

Since 1977, Japan has chosen to develop the liquid fed ceramic melter. The first Japanese vitrification facility at Tokai (TVF) was licensed by the Japanese authorities in early 1988 and construction began later that year. The TVF will start operation in 1992. The design capacity of the TVF is fitted to the Tokai reprocessing plant. The glass production rate is about $9 \mathrm{Kg} / \mathrm{hr}$. About $300 \mathrm{Kg}$ of glass will be poured periodically from the bottom of the melter into a canister.

The PNC development program has resulted in a melter structure with a steeply sloped floor, glass additive using a fiberglass frit cartridge and a two zone induction heated freeze drain valve.

The melter structure with sloped floor was developed as a measure to effectively remove the conductive sludge from the bottom drain. At PNC, melter tests using a 45 degree sloped bottom showed that no significant change in joule heating between electrodes has been observed and more than $90 \%$ of the noble metal elements fed into the melter were discharged through the bottom drain. The proposed design for the resulting TVF melter is shown.

The melter freeze valve drain design uses a two-zone induction heating system. Separate heating of the tip of the drain has been found effective to eliminate the formation of glass string.

Modelling tests have been performed with a three electrode steep sloped floor design melter. The results were very encouraging and showed with copper powder to simulate precipitates, that such a design would be effective for heating and stirring the melt homogeneously in the melter.

The extenided research work on the feed system and melter off-gas treatment system led to the process flowsheet shown.

A reprocessing plant of Japan Nuclear Fuel Services (JNFS) will be constructed to begin operation about 1977. Annual capacity for this plant will be 800 tons, four tons per day. The ceramic melter development program at PNC and plans for the Tokai Virification Facility (TVF) have led to the selection of two ceramic melter lines to give capacity equivalent to the reprocessing plant. 


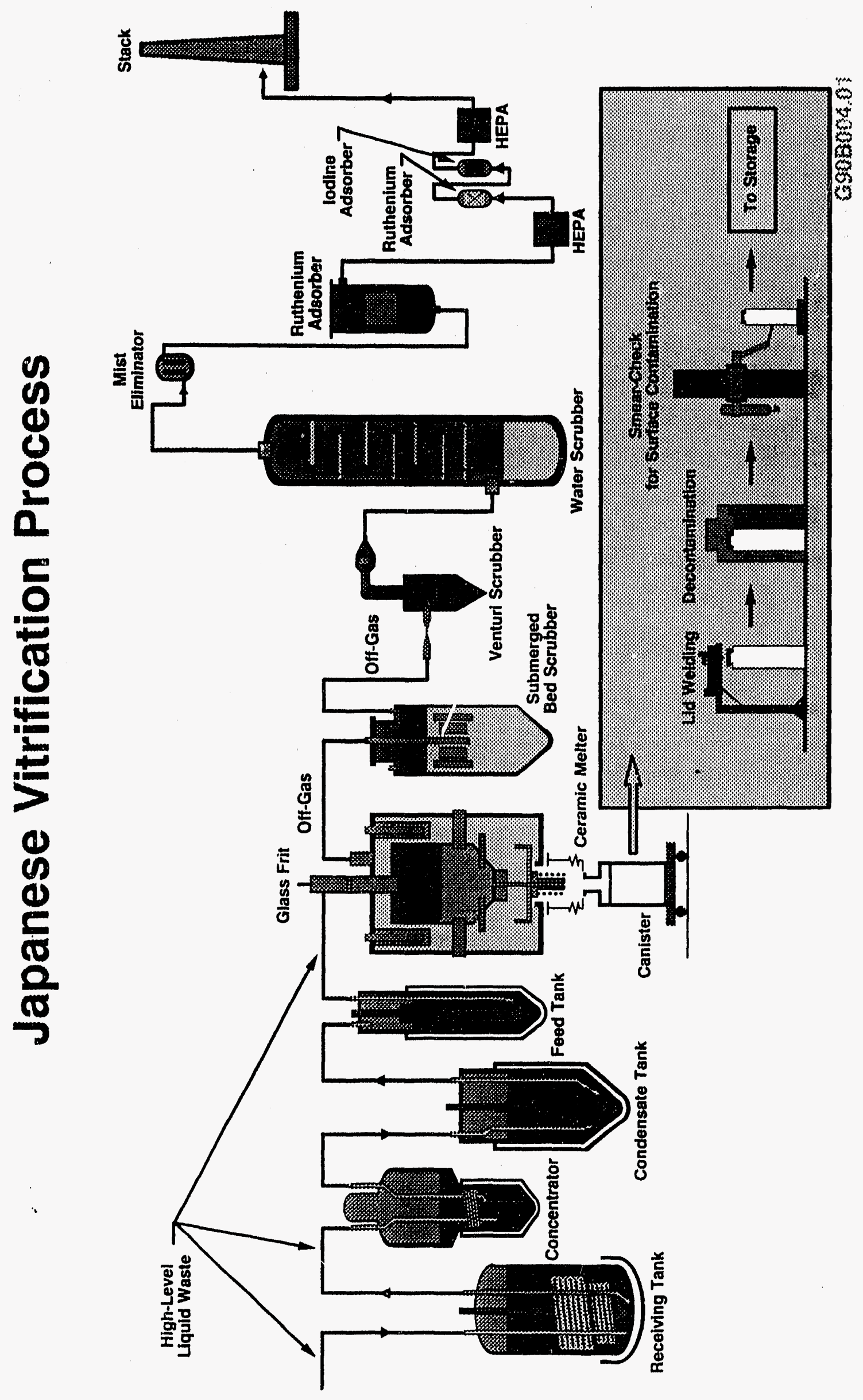




\section{Structure of Melter}

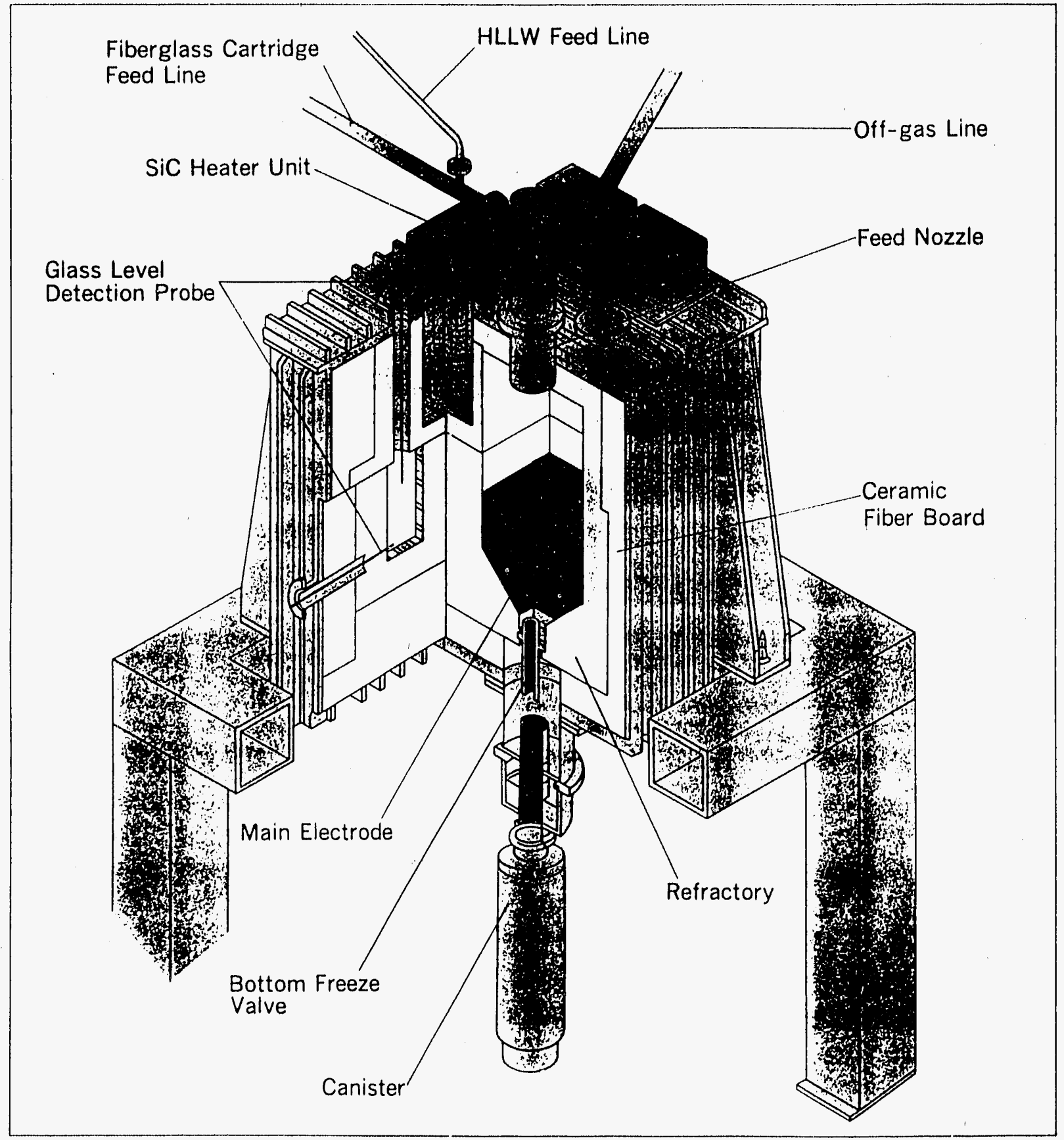




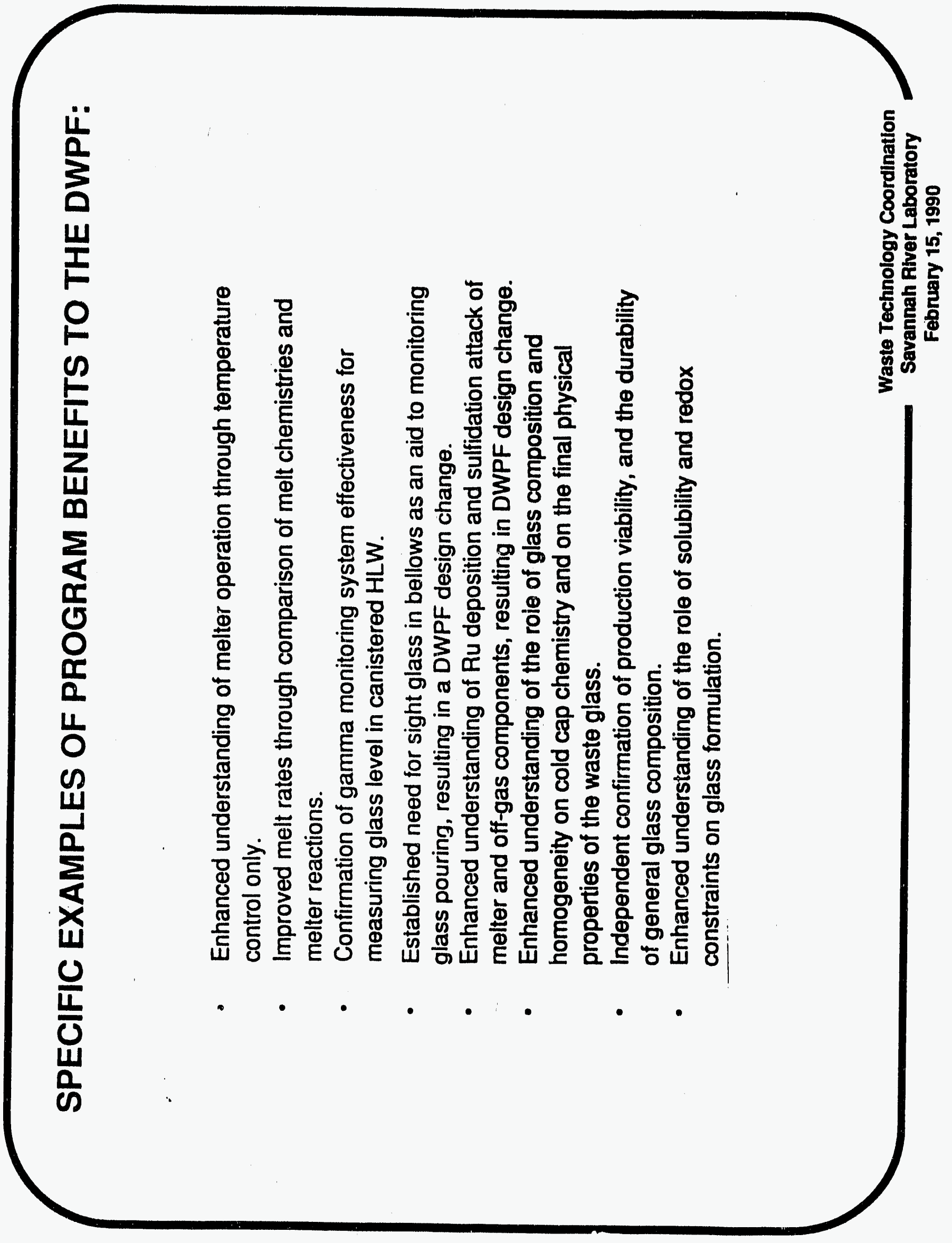





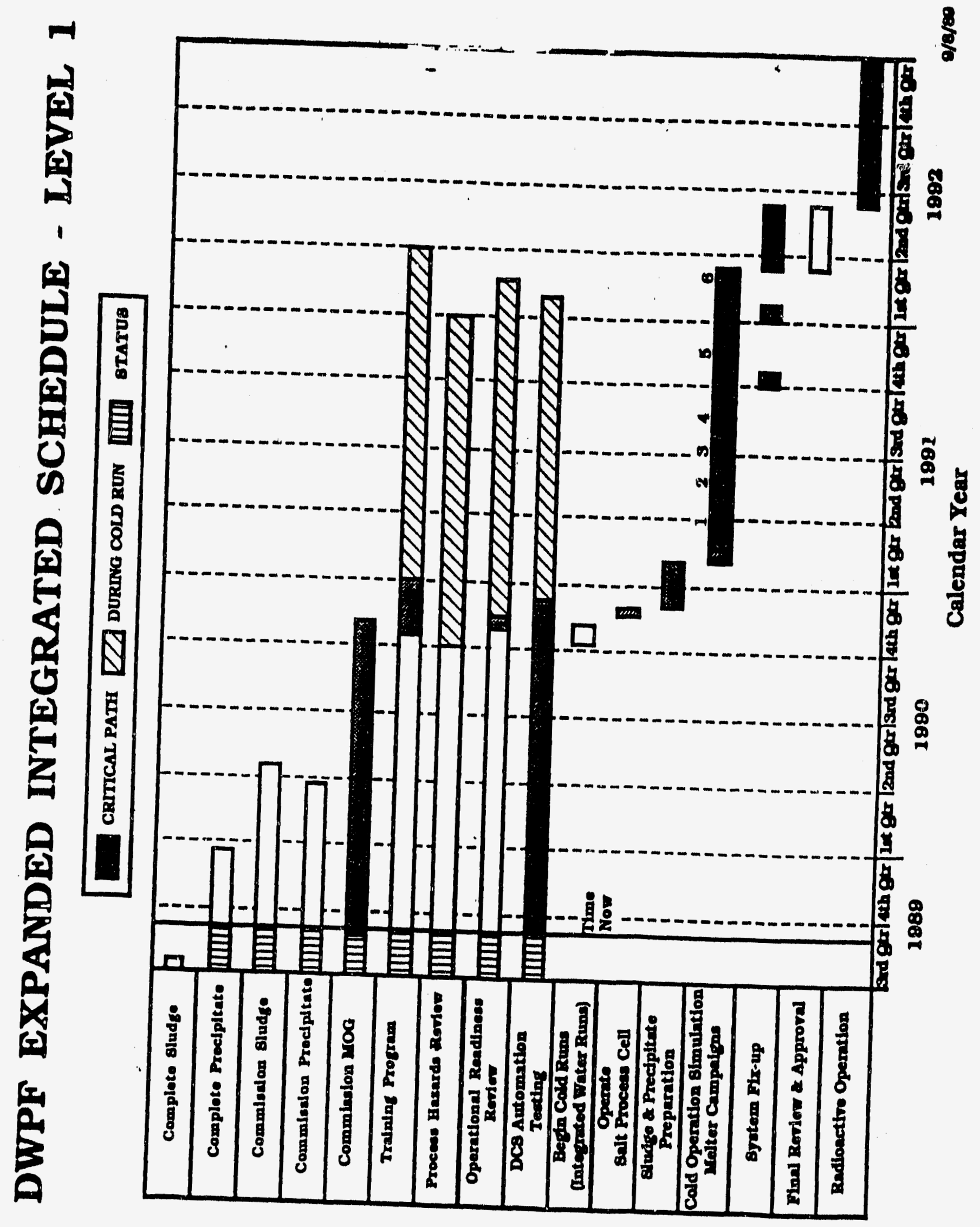



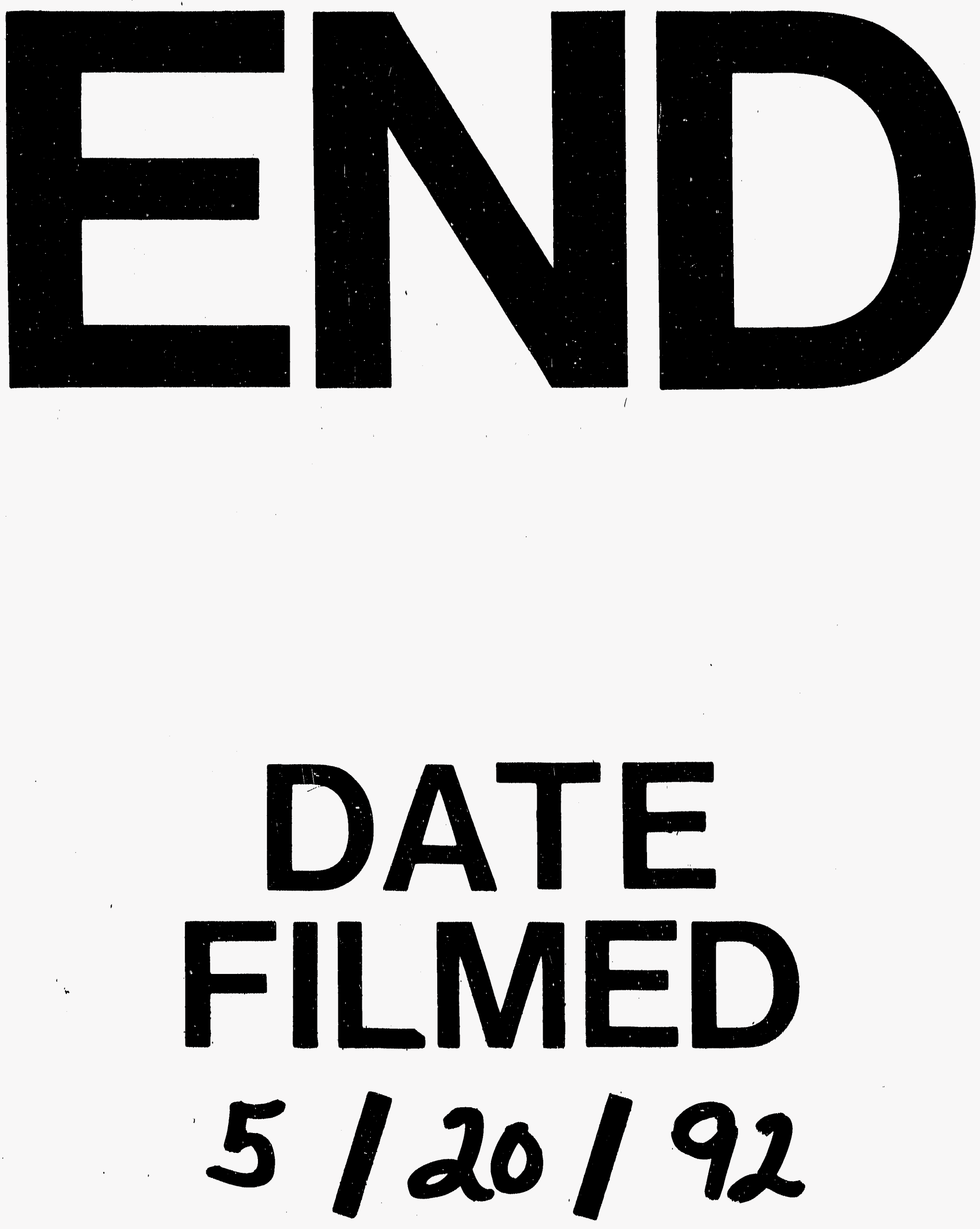
